\title{
COMMUNICATION WITH CLIENTS USING ELECTRONIC MAIL - ANALYSIS OF THE EXPECTATIONS OF VARIOUS MARKET SEGMENTS
}

\section{IZABELA OSTROWSKA}

University of Szczecin, Faculty of Management and Economics of Services, POLAND

e-mail: izabela.ostrowska@wzieu.pl

RECEIVED
ACCEPTED
JEL
CLASSIFICATION

KEYWORDS

ABSTRACT
18 January 2018

2 September 2018

D12, D22, D83, M19, Q41

marketing, qualitative research, e-mail communications, energy supplier

This article is a part of the series of publications on written communication. The aim of the article is to evaluate the possibilities of electronic communication with individual market segments and to identify key elements of e-mail communication and to adapt them to the preferences of clients. Three segments of consumers were identified in the research - young people (up to 40 years old), mature ones (over 40 years of age) and corporate consumers. Each of these groups has different habits regarding communication, which they transfer to relationships with suppliers of goods and services. Older people communicate with energy supplier mostly by mail or by visiting the customer service point personally. Younger people choose electronic communication or via the hotline. Entrepreneurs' representatives most eagerly handle matters by e-mail.

\section{Introduction}

Corporate correspondence, especially e-mail, should be personalized, which is often difficult to achieve with a large scale of the company's operations. Large organizations recognize the need for a deeper analysis of changes in customers' purchasing behavior, understanding their preferences and written correspondence, to adapt this form of communication to the expectations of their recipients. 
From the point of view of effective communication, it is important to form the message so that it is properly understood, to determine what permanent elements such correspondence should contain and how to plan it visually. For this reason, qualitative research was carried out in cooperation with a Polish large energy company (electricity seller, one of the five largest energy sellers in Poland). An energy company, which has about 2 million customers, sends thousands of traditional letters every day, and every employee dealing with electronic correspondence responds to dozens of customer inquiries. In traditional correspondence, but also e-mail correspondence, it makes it necessary to use ready-made response templates that employees can additionally modify. It is important that these templates are professionally prepared, easy to personalize and, above all, adapted to the changing expectations of customers. More and more consumer inquiries are addressed via e-mail or inquiries from the e-BOK (Electronic Service Office). Then the company's response should also be sent via e-mail.

This article is a publication from the series on written communication. The aim of the article is to evaluate the possibilities of electronic communication with individual market segments and to identify key elements of e-mail communication and to adapt them to the preferences of clients. Three segments of consumers were identified in the research - young people (up to 40 years old), mature ones (over 40 years of age) and corporate customers. The division into segments results from to the specificity of the energy industry, and the large age range of young people is due to the fact that people starting their own households in Poland are mostly people aged 30 years.

\section{Litepature review}

Communication research is an important area of studies related to the activities of the organization, because properly conducted communication with clients, but also with co-workers enables efficient running of the company and effective sales (including Bavelas, Barret, 1951, pp. 366-371; Simon, 1976, pp. 157-162; Darf, Legel, 1984, pp. 191-233; Engel, Warshaw, Kinnear, 1998; O'Sullivan et al., 2005; Murphy, Sashi, 2018, pp. 1-12; Hossain, Chonko, 2018, pp. 221-234).

Stankiewicz draws attention to the important aspect of written communication. Communicating between people in this way allows the use of words that constitute about $7-10 \%$ of all messages transmitted. Therefore, the sender of the message has definitely less opportunities to influence the recipient (Stankiewicz, 1999, p. 111). Written communication has the basic advantage, i.e. the permanent preservation of the information contained therein, and thus it is easy to archive (Trocki, 2012, p. 321). Written communication is appropriate when it is necessary to provide precise information, and also if the parties are unable to meet directly.

Written communication in organizations is classified as formal communication. Formal communication is usually based on written letters and documents, while informal communication is based on direct meetings (Darf and Legel, 1984, pp. 191-233). Researchers have noted that formal communication is needed to perform specific procedures, while informal communication is necessary to develop a business (Murphy, Sashi, 2018, pp. 1-12; Hossain, Chonko, 2018, pp. 221-234.).

It is worth noting that written communication is a skill that can be learnt in the education process. In the era of electronic communication, when many matters are discussed in e-mails, it becomes the basic competence of employees. Written communication is one of the basic (generic) business skills (Calma, 2013, pp. 35-50). Companies pay more and more attention to this skill, also during the recruitment process of potential employees (Krapels, Davis, 2003, pp. 90-96). To meet these expectations, universities also try to prepare students, including written communication to one of the key business skills (Addams, Allred, 2015, pp. 250-263). 


\section{The specificity of e-mail communication}

The literature discusses three basic models of marketing communication, the use of which is conditioned by the specificity of the company's operations, resources possessed, market situation and customer relations. These are: mass communication, interpersonal communication and communication in hypermedia computer environment. The first two models are traditional in nature, while the third model combines the possibilities of these previous models, and additionally enables the groundbreaking introduction of changes in the rules of marketing communication. The message itself is more varied - it can have a multimedia form, i.e. text combined with additional visual forms (such as: drawing, animation, film), but also sound (music, read message). The content and form of the message is changing qualitatively, but the roles of the participants and the direction of information flow are also subjected to alterations (Blythe, 2002, pp. 13-15; Wiktor, 2013, p. 42; Kramer, 2013, p. 11; Taranko, 2015. p. 36; Rosa, Słupińska, Ostrowska, Gracz, 2018).

Email communication became popular due to its key advantage: easy and rapid exchange of information that simplifies communication in large and geographically distributed organizations (Sproull, Kiesler, 1991, pp. 84-91). Another advantage is its low cost and the ability to accurately describe the case. Communication via e-mail is also related to threats. Sending emails to many recipients requires only a modicum of effort since they do not have to be printed out and delivered to a post office. The consequence of this increased quantity of emails is obvious: inboxes become jam-packed and result in a confusing mixture of relevant and irrelevant emails, which hinders efficient information processing (Soucek, Moser, 2010, pp. 1458-1466; Whittaker, Sidner, 1997, pp. 71-83).

Compared to business letters, email communication is often considered a spontaneous and less formal communication medium (Nantz, Drexel, 1995, pp. 45-49). This notion of email communication often leads to superficially and ambiguously formulated messages that fail to give the recipients enough information to act upon, and therefore fosters misunderstandings (Burgess, Jackson, Edwards, 2005, pp. 71-83). Researchers point out that e-mail communication can cause misunderstandings because e-mail communication rules are not well developed and are not generally accepted (Kiesler, Siegel, McGuire, 1984, pp. 1123-1134). One example of ambiguity due to unclear communication rules occurs when senders expect recipients to respond to a message within a short time frame (Markus, 1994, pp. 502-527; Renaud, Ramsay, Hair, 2006, pp. 313-332; Soucek, Moser, 2010, pp. 1458-1466.).

Persons communicating in writing must be able to organize and clearly express their thoughts and adapt them to the specifics of formal or informal correspondence. This requires matching the message, vocabulary and form to the circumstances and the recipient, to communicate with its addressees in the best possible way (Simerson, Venn, 2010, p. 197).

\section{Method}

The presented research results were carried out in Szczecin, in the focus workshop in the Service Inter Lab center from 13.06 to 6.07.2017. The research team responsible for the scenario of the research, selection of respondents and moderation of interviews included: G. Rosa, I. Ostrowska, L. Gracz, K. Słupińska. The energy company provided sample templates of written communication and participated in adjusting the scenario of the research to the specifics of the industry. People using the services of the energy company, selected in a targeted 
manner were the respondents. Differentiating criteria included: gender, age, education, as well as the type of customer - individual or business.

In the first stage of the study, three focus group interviews (FGI) were conducted - two among individual consumers divided into young people (up to 40 years of age) and mature people (over 40 years) and one of the company's representatives. During the second stage of the study, i.e. the verification stage, two research groups were accepted - individual persons and corporate customers. Each group interview (FGI) was attended by 7-8 participants, this is the optimal number due to the duration of the study and possibility of an effective examination.

The objectives of the focus studies and individual interviews were as follows:

Objective 1: Analysis of customer behavior and preferences regarding written communication.

Objective 2: Analysis of the current state of written communication in visual terms.

Objective 3: Analysis of selected elements of the written message in terms of its affordability.

The letters presented during the research were, for example, personalized letters and e-mails, prepared on the basis of templates from the energy company, which concerned the most common topics in correspondence with clients.

\section{Resullts}

\section{Segment of mature consumers}

Individuals who were considered mature in the study (over 40 years of age) can be divided into additional segments due to the use of respondents aged 35 to $44.87 \%$ of people use the network, and only $45 \%$ of people from 45 to 54 years of age use the Internet. Over half of people aged 55-64 and three-quarters of the oldest Poles $(65+)$ do not use the Internet at all (CBOS, 2017, p. 2).

In the group of mature clients after the age of 40 , the barriers to Internet use are noticeable. The respondents prefer to get a paper invoice. In this group, many people pay their bills in a very traditional way, i.e. in post offices. In this group of respondents, only a few people aged 40-60 still pay bills via electronic banking, but they also have a reluctance to use an electronic service office. Even the login process on the site is a problem for older people they are afraid to provide their data.

Older people who use the Internet, consider the form electronic communication with the company as convenient. Due to the short, specific form of e-mails, this form of communication is even preferred. An important advantage of e-mails is the possibility of archiving them. Most older respondents stated that they do not use e-mails in formal correspondence with companies and prefer to send a traditional letter, due to greater certainty that the message will reach the recipient and the opportunity to send a registered letter with confirmation of receipt.

The respondents also evaluated sample letters and e-mails from the energy company. In comparison to traditional written communication, e-mail correspondence has been very positively evaluated, especially the conciseness of the information provided and its affordability. In the company being researched, a separate department is responsible for electronic correspondence, people employed in it are trained so that the correspondence would not be too extensive.

The presented e-mails contain graphic ads, which were also evaluated - especially if they do not disturb the reception of the message content. For the respondents, it is preferable that the graphics with advertising offers are active so that after clicking you can enter and read the details of the offer on the website. Thanks to the appropriately worded e-mail subject, credible sender's address, and the headline with the logo of internet communication. There 
is a greater diversity in the examined age group. Among the energy company, participants believe that it is easier to identify the sender and they feel safer.

\section{Segment of young customers}

Internet usage is common among the youngest Poles $18-24$ years (100\% Internet users) and almost universal among people aged 25-34 (96\%). Among respondents from 35 to 44 years it is $87 \%$ of people (CBOS, 2017, p. 2).

Young people prefer e-mail correspondence because of its virtual character and the possibility of checking it from different places. It is also easier to find it in the e-mail box and later reach the given information. Communication through this channel is faster and cheaper. The only advantage of the paper magazine is that it contains stamps, subject, customer number, which are included in the content of the letter.

As a start of the e-mail, you can put the formula "thank you for contact", which is perceived positively by the young. However, in the case of unpleasant matters for the client - e.g. complaints, it is worth to refer directly to the matter and no longer thank for the contact. The content of the e-mail should be short and written in a simple language, with an indication of what steps the client should take or what is the outcome of the case. The signature of the person writing the e-mail should be on the left side, which is generally accepted in electronic correspondence. Each customer application, which is sent from eBOK or from a form on the website, should also be made available to this customer.

\section{Corporate customer segment}

The business client can be very different target groups - from large organizations from the public sector, through large and medium-sized companies to representatives of the SME sector. Consumers from the business segment are considered extremely demanding: and well-educated. They have the specialist knowledge necessary to properly assess the offer. They are constantly monitoring changes on the market, and the product search begins with a comprehensive analysis of available solutions. The business consumer should be treated as a partner, which is why the value of the ability to conduct dialogue with it is strongly emphasized (Urbaniak, 1999, pp. 14-21).

Entrepreneurs prefer electronic correspondence, they are eager to use this form of communication, because it improves the process. The use of this form of communication between companies allows for better time management. Rice and Bair (1984) believed that the use of electronic media would increase both personal and organizational productivity. The respondents appreciate that in this type of communication they decide when they open the e-mail, no one interferes with their schedule of the day and they do not have to wait on the infoline to learn something. However, this kind of correspondence should benefit from all amenities for clients. For example, an e-mail with an invoice attached - the content should contain short information about the amount to be paid, payment date and a link to the online payment form.

The respondents were presented with an example of an e-mail from an energy company the upper part of contained an advertisement encouraging the use of e-BOK. According to the respondents, the pictures with the advertisement are too big, they do not always open and then there is empty space in the content, which does not look professional. The question whether such an e-mail could be treated as an advertisement and deleted was answered that it is possible. However, in the case of electronic messages, the subject of the message is very important, depending on whether the e-mail with the advertisement is not treated as spam or strictly advertising 
message. There is a suggestion to place an ad below the relevant content of the message so that it does not interfere with the reception of the most important content.

\section{Conclusions}

E-mail correspondence contains permanent elements relevant to the addressees. The first element indicated is the subject of the e-mail, which should be formulated briefly and clearly to inform what the correspondence relates to. The content of the e-mail should be short and written in a simple language, with an indication of what steps the client should take or what is the outcome of the case. The signature of the person writing the e-mail should be on the left, which is generally accepted in electronic correspondence. Each customer application, which is sent from eBOK or from a form on the website, should also be known to this customer. In the case of electronic communication, the time of responding is important as the respondents emphasized that they expect an answer to the email within 1-2 business days.

In correspondence in the hypermedia environment, the company should use all amenities for clients. E-mails to customers should be sent from the address with the possibility of replying them so that the customers do not have to look for an address on the company's website. E-mail with attached invoice should contain short information about the amount to be paid, payment date and a link to the form allowing online payment. A graphic ad may be included in emails, but it must be a link to the page with the details of the offer. If the graphic with the advertisement is placed on the top of the message, then the respondents notice the risk of not reading the message. For this reason, they suggested that promotional content may be on the side of the message or under the right message, always with the possibility of automatic redirection to the source page.

From the company's point of view, the electronic communication channel is first of all cheaper, more environmentally friendly and simplifies management processes (preparation of printouts, packing letters and sending them). However, taking into account customer expectations, electronic communication channel is only possible to use in certain market segments. Young people (up to 40 years old) and entrepreneurs consider this communication channel to be the right one because of their comfort and habits. Meanwhile, older people are of the opinion that communication with companies should take place in a more traditional way. They are concerned about the lack of material evidence in electronic communication and the risk of transferring their data to unknown entities. It can be anticipated that in the coming decade more and more people will also benefit from this type of communication in this age group, which is due to the fact that current young people will enter adulthood and their habits will not change in this respect.

\section{References}

Addams, L.H, Allred, A.T. (2015). Business communication course redesigned: all written and oral communication assignments based on building career skills. Academy of Educational Leadership Journal, 19 (1), 250-263.

Bavelas, A., Barrett, D. (1951). An Experimental Approach to Organizational Communication. Personnel, 27, 366-371.

Blythe, J. (2002). Komunikacja marketingowa. Warszawa: PWE.

Burgess, A., Jackson, T.W., Edwards, J.E. (2005). Email training significantly reduces email defects. International Journal of Information Management, 25 (1), 71-83.

Calma, A. (2013). Fixing holes where the rain gets in Problem areas in the development of generic skills in business. Journal of International Education in Business, 6 (1), 35-50.

CBOS (2017). Korzystanie z internetu. Komunikat z badań nr 49/2017. Warszawa. 
Daft, R.L., Lengel, R.H. (1984). Information richness: A new approach to managerial behavior and organization design. In: L.L. Cummings, B.M. Staw (eds.), Research in organizational behavior: Vol. 6 (pp. 191-233). Homewood, IL: JAI Press.

Engel, J.F., Warshaw, M.R., Kinnear, T.C. (1998). Promotion Strategy. Chicago: Irwin.

Hossain, M.T., Chonko, L.B. (2018). Relational communication and illusionary loyalty: Moderating role of selfconstrual. Industrial Marketing Management, 69, 221-234.

Kiesler, S., Siegel, J., McGuir, T.W., (1984). Social psychological aspects of computer-mediated Communications, American Psychologist, 39, 1123-1134.

Kramer, J. (2013). System informacji i komunikacji marketingowej wobec wyzwań gospodarki opartej na wiedzy i mądrości. In: A. Bajdak (ed.), Komunikacja marketingowa - współczesne wyzwania i kierunki rozwoju. Katowice" Wydawnictwo Uniwersytetu Ekonomicznego.

Krapels, R.H., Davis, B.D. (2003). Designation of "Communication Skills" in Position Listings. Business Communication Quaterly, 66 (2), 90-96.

Markus, M.L. (1994). Electronic mail as the medium of managerial choice. Organization Science, 5, 502-527.

Murphy, M., Sashi, C.M. (2018). Communication, interactivity, and satisfaction in B2B relationships. Industrial Marketing Management, 68, 1-12.

Nantz, K.S., Drexel, C.L. (1995). Incorporating electronic mail into the business communication course. Business Communication Quarterly, 58, 45-49.

O'Sullivan, T., Hartley, J., Saunders, D., Montgomery, M., Fiske, J. (2005). Kluczowe pojęcia w komunikowaniu i badaniach kulturowych. Wrocław: Astrum.

Renaud, K., Ramsay, J., Hair, M. (2006). “You've got e-mail!”... Shall I deal with it now? Electronic mail from the recipient's perspective. International Journal of Human-Computer Interaction, 21, 313-332.

Rice, R.E. (ed.) (1984). The new media: Communication, research and technology. Beverly Hills, CA: Sage.

Rosa, G., Ostrowska, I., Słupińska, K., Gracz, L. (2018). Komunikacja międzykulturowa. Kraków: eduLibri.

Urbaniak, M. (1999). Marketing przemysłowy. Warszawa: Wydawnictwo Prawno-Ekonomiczne Infor.

Simerson, B.K., Venn, M.L. (2010). Menedżer jako lider. Warszawa: Oficyna a Wolters Kluwer business.

Simon, H.A. (1976). Administrative Behavior: Study of Decision-Making Processes in Administrative Organization. New York, NY: Free Press.

Soucek, R., Moser, K. (2010). Coping with information overload in email communication: Evaluation of a training intervention. Computers in Human Behavior, 26 (6), 1458-1466.

Sproull, L., Kiesler, S. (1991). Computers, networks and work. Scientific American, 265, 84-91.

Stankiewicz, J. (1999). Komunikowanie się w organizacji. Wrocław: Astrum.

Taranko, T. (2015). Komunikacja marketingowa. Istota, uwarunkowania, efekty. Warszawa: Oficyna a Wolters Kluwer business.

Trocki, M. (2012). Nowoczesne zarządzanie projektami. Warszawa: PWE.

Whittaker, S., Sidner, C. (2005). Email overload: Exploring personal information management of email. International Journal of Information Management, 25, 71-83.

Wiktor, J.W. (2013). Komunikacja marketingowa, Modele, struktury, formy przekazu. Warszawa: Wydawnictwo Naukowe PWN.

Cite this anticle aS: Ostrowska, I. (2018). Communication with clients using electronic mail - analysis of the expectations of various market segments. European Journal of Service Management, 3 (27/2), 315-321. DOI: 10.18276/ejsm.2018.27/2-38. 